\title{
Acceptance of the Howland Award: Two Dilemmas for Teachers of Clinical Medicine
}

\author{
HARRY H. GORDON(32) \\ Department of Pediatrics and Rose F. Kennedy Center for Research in Mental Retardation and Human \\ Development, Albert Einstein College of Medicine-Yeshiva University, Bronx, New York, USA
}

\begin{abstract}
When Frederick Robbins phoned last year to invite me to this happy occasion, he introduced the subject by saying that I had many friends. I did not do as Powers had done in 1947: call one or more members of the Borden Award Committee to reassure himself that their judgment had not been clouded. Rather, I bask in the warmth of your friendship and say that $I$ feel the same way about you. I thank Barton Childs for his kind words and even more for the example of his constancy in pursuit of the highest ideals of this society, ideals transmitted from Howland by Park to Childs.

Some awardees have chosen to present profiles of their important teachers; e.g., Taussig spoke of Park, and Diamond of Blackfan; others have addressed themselves to specific subjects: Powers to mental retardation, Dunham to the use of the opossum as an animal model for those interested in prematurely born infants. In a first draft, I did both and ended with a far too lengthy paper. The verbosity supported Park's statement, on the occasion of the first award, that longevity was apparently a necessary attribute of awardees. There is more direct evidence. The mean age of the seventy-four awardees is 71 years; the standard error of the mean is 0.79 , a datum which supplies an answer for which, as Albert Dorfman says, there is no question. The true range is not from 64 to 77 years, but from Daniel Darrow, clinical scientist, to Martha Eliot, public servant, and Bela Schick, clinician and teacher.
\end{abstract}

Others as well as I have written elsewhere of the great teachers from whom I was fortunate to learn. They differed in personality, background, and skills but possessed a common bond of integrity and devotion to the pursuit of excellence. Brief comments I do make because the present, be it exciting or "just so daily" easily overwhelms the past; biographic references are appended for those who wish to read more. These women and men represent the cultural heritage from which stem the opinions to be expressed about two dilemmas for clinical teachers; the quest for certainty and the "full time" system.

David Marine (1880- ) was director of laboratories at Montefiore Hospital from 1920 to 1945 (1). My internship in pathology provided my first intimate contact with a person whose imaginative mind and encyclopedic knowledge opened exciting vistas for exploration. His work in Cleveland had led to widespread iodination of salt for prevention of goiter in children. In 1927, he reported hyponatremia and hypernatriuria in adrenalectomized cats, several years before Loeb made similar findings, independently, in patients with Addison's disease. He permitted me to submit my first paper for publication but with some disdain because it contributed nothing to his knowledge. His card files already contained all of the references I had found without benefit of his files. He obviously believed strongly in the work ethic. It is to the credit of the Montefiore Hospital that in 1920 they appointed an experimental pathologist as Director of Laboratories in a voluntary community hospital, evidence of their early concern for research as one of their functions. Medical students now reap benefits from the complementary strengths of the Albert Einstein
College of Medicine and the Montefiore Hospital and Medical Center as do the institutions and their faculty.

Marine asked me in 1929 why the adrenal glands of prematurely born infants involute after birth as do those of full term infants. The answer required thinking about the effects of birth in more subtle ways than of a torn falx. For those who have become interested in the risks to mother-child attachment inherent in common nursery practices, I quote the refrain from a ditty written by Milton Levine almost 50 years ago:

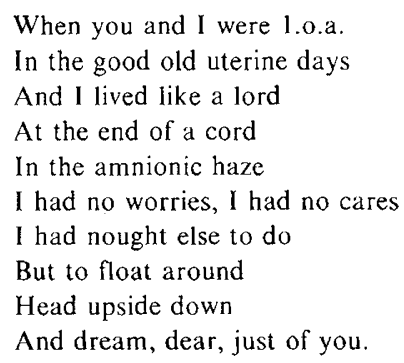

The "dear" of this ditty was born prematurely. Is it possible that an ingenious neonatologist may lead us back to swaddling premature babies, with monitors and catheters in appropriate place? Should all this be on a water bed in a quiet incubator? Wouldn't it be even better if the programs from maternity and infant care which have decreased the incidence of low birth weight infants were extended to all rather than only some poor mothers?

Grover Powers (1887-1968) was Chairman of the Department of Pediatrics at Yale from 1928 to 1951 (2). (I was referred to New Haven in 1930 by one of his former students; he told me of the new professor who was a remarkable clinician and teacher but who was not well known because he never worked in the laboratory and therefore didn't publish many papers). Dr. Powers turned me toward academia early in my pediatric internship; his model made it clear that I wouldn't have to give up an adolescent's dream of becoming a baby doctor. He attracted medical students to pediatrics by, as one former student said, "just being."

Powers repeatedly asked on ward rounds: What is this little baby trying to tell us? I have written elsewhere "forever ours became the responsibility to try to understand the small infant or toddler; the adolescent or young soldier; the mother who has language difficulty because she is an immigrant from a foreign country or from rural areas; the culturally deprived; the emotionally disturbed; the mentally retarded; those dumb or those garrulously inarticulate with anxiety." On the basis of my past 13 years' experience in a big city's municipal hospitals, I add the responsibility to the poor or marginally poor, one, but only one element of whose despair is their inability to choose their own physicians. It is a big challenge to win and deserve to keep the confidence of patients who haven't chosen you as physician, be they poor people, soldiers, the incarcerated, or institutionalized.

Oscar Schloss (1881-1952) was professor of pediatrics at 
Cornell from 1919 to 1952 , serving as chairman from 1919 to 1934 , except for a 2-year stint as chairman at Harvard (3). Although he was in private practice for almost his entire career, he found time working in the laboratories at Bellevue and the Nursery and Child's Hospitals to prove the existence of allergy to foods, and independently of Howland and Marriott, of the acidosis and importance of impaired renal function in infantile diarrhea. $\mathrm{He}$ insisted that I maintain general pediatric skills by working in the outpatient department during my years of research experience with S. Z. Levine (4), and this for reasons only partly dictated by prudence during years of economic depression and institutional prejudices. I am grateful too for the example of his versatility and scholarliness.

Ethel C. Dunham (1883-1969), Director of the Division of Research in Child Development of the Children's Bureau, spurred my interest and that of Dr. Levine in the families to which we were discharging prematurely born infants from the air-conditioned nurseries of the New York Hospital (5). She also introduced me to Needham's Chemical Embryology, the stimulus for a laboratory later established as a joint enterprise of the Departments of Obstetrics and Pediatrics at the University of Colorado. Her mimeographed sheets were the forerunners of the Standards and Recommendations for Hospital Care of Newborn Infants of the American Academy of Pediatrics.

Alfred H. Washburn (1895-1972), Director of the Child Research Council of Denver, had a fierce social concern for the individual (6). He knew that normality could be interesting out beyond two standard deviations. He used his measurements and those of his colleagues to buttress the view that the bedrock of clinical practice is respect for human variation.

John Benjamin (1901-1965) was Professor of Psychiatry at the University of Colorado and a member of the Child Research Council (7). Psychoanalytically oriented, his brilliant mind and broad interests permitted him to initiate lively discussions with visiting scientists from many disciplines in seminars on Fundamental Biology and Biophysics. With Bernstein, he showed that petted rats gained more than unpetted ones in association with a diminished ${ }^{131}$ I uptake by the thyroid rather than an increased food intake. He spurred Metcalf to study the ontogenesis of sleep spindles in the electroencephalograms of newborn infants and could distinguish between ontogenetic and postnatal, i.e., experiential, characteristics. His was wise counsel, much sought by house officers, colleagues, friends, foundations, the National Institutes of Health. He recognized the dangers of reductionism in thinking about child development, and introduced me to Sibylle Escalona who continues to remind me of the need for a holistic approach (8). With John Benjamin, a psychiatrist interested in molecular biology, Theodore Puck, a biophysicist-molecular biologist interested in people, Stewart Taylor, an obstetrician interested in babies, and Florence Sabin (9), who had gone from a professorship of anatomy at Hopkins to membership in the Rockefeller Institute, and finally to a career in public health administration in Denver, an atmosphere existed in which one could conceive a multidisciplinary research effort in child development that would range from molecule to community. The conception ultimately became the Rose Kennedy Center for Research in Mental Retardation and Human Development, now coming to its fifth anniversary.

Edwards A. Park (1877-1969) was professor of pediatrics at Yale from 1920 to 1928 and at Johns Hopkins, as John Howland's successor, from 1928 to retirement in $1947(10)$. His contributions to histologic identification of the osseous lesions in McCollum's rats as those of human rickets was a landmark. No one can, however, do justice to this man, beloved and respected by so many in this audience and who at the time of his Borden Award for nutritional research would only take credit for facing young people in the right direction. It was not my good fortune to come in close contact with this great mind and spirit until 1952. He didn't remember and I never reminded him that I was refused an internship at Harriet Lane and thus never had to choose between Baltimore and New Haven. Recognizing Powers' clinical skilis, teaching ability, and sensitivities, Park had kept him in academia to serve as a role model for many of us. I am grateful, too, for Park's support when I chose not to take the Harriet Lane premature nursery into the national cooperative study of retrolental fibroplasia. He agreed that already promising animal studies would suffice as a complement to the clinical data that were beginning to appear.

As many of you are fortunate to know, Dr. Park wrote many letters; Helen Taussig used some in preparing her Howland Award address in 1971. I add one item. Miss Helen Schnetzer, a former nurse in our metabolic unit at New York Hospital, was the chief nurse at Harriet Lane during the last years of Dr. Park's chairmanship; she left her post at age 38 because of an inoperable carcinoma. Each morning for months of her painful, terminal illness there was a letter from Dr. Park. Reading it was the high spot of her day. She then returned to the haze of her pain-killing drugs.

I mention, too, my father, an immigrant from the Russian Pale via Argentina. He instilled a love of learning for its own sake, "neither as a crown of glory, nor a spade to dig with," a worthy heritage from a culture that wasn't concerned with academic promotion or research contracts. And I speak of Dr. John Robertson, a general practitioner whose sensitivity to our family's needs in the early part of this century was not obtunded by cultural and ethnic differences. His example led me to a choice of medicine as a career; in his terminal illness his parting advice was " $\mathrm{Be}$ honest with yourself."

Finally, I am grateful to "fellow students" of all ages who by their questions and disagreements helped to hone my reasoning, and to the practitioners with whom I worked in New Haven, New York, the United States Army, Denver, and Baltimore, men and women dedicated to giving good care to patients, and with a perspective that I found necessary and instructive.

All this may help you understand the background of the opinions now to be presented. Mary Ellen Chase writes that longevity frees one from the "shackles of time (and) its half truths." From this vantage point, I discuss two continuing dilemmas for clinical teachers. Our educational system contributes, albeit unintentionally, to the complaints of people at all social levels that doctors don't think of them as people. Acceptance of excuses that extreme competition for admission to medical school, faulty criteria for choice by admission committees, overwork after graduation are wholly responsible for doctors' apparent or real callousness stultifies critical examination of the educational process itself. It generates "catch-22" escapism that does not satisfy perceptive patients or their representatives in the patient advocates' offices which exist in too few of our large hospitals. (A priori, isn't it sad comment that patients should need advocates in our medical centers?) Skeptics attribute the callousness of doctorsin-training to the models set by members of clinical faculties who "use" patients for primary purposes of the medical school, teaching and clinical research, and who seem to forget that setting standards of patient care worthy of emulation is also a primary and necessary purpose of the medical school.

Critics understand but do not accept as overriding, the validity of concepts like "statistical morality," or "statistical compassion," the former representing the constant ethical dilemma of balancing individual rights with societal benefits $(11,12)$. The critics challenge our institutional mores; we must accept the challenges if for no other reason than that unanswered they overflow into skeptical, at times punitive, attitudes by legislators, ethicists, lawyers, and juries, all of whom may have experienced or seen examples of abrasive callousness.

Shouldn't we listen to the protests of students, expressed more vociferously a few years ago, about "dehumanization" in the clinical years? Korsch's audiotapes, Helfer's videotapes, Duff and Hollingshead's study of "Eastern University," Richmond's analysis of the development of medical care and education document the students' charges $(13 \cdots 16)$. Why do students lose the interest in interpersonal relationships and dis-ease of patients 
exhibited in the freshman year and substitute interest only in disease? Why is it too much to maintain both? I think part of the answer is in the model set for them, in the best of will, by some of their justly prestigious and influential teachers.

\section{THE QUEST FOR CERTAINTY-TOLERANCE FOR UNCERTAINTY}

One factor is the quest for certainty, a necessary ingredient of medical practice and research. This quest has led to advances in laboratory and clinical science, technology, our understanding of disease mechanisms, diagnosis, and care of patients which none of us as physicians and none of our patients or their families would knowingly forego. Arriving at the correct diagnosis of a complex illness serious enough to have brought the patient into the hospital carries the joy of the quest, the joy of the use of new diagnostic measures, the joy of achievement which is even greater if effective therapeutic measures crown one's efforts, the joy of doing something immediately for the patient. But what if the patient's illness doesn't require hospitalization or if analysis of the symptoms doesn't even warrant a comprehensive diagnostic effort? What if in ferreting out the cause of the smoke one finds no, or only a smoldering, fire? Interest dwindles on the part of both teacher and student. One reason is that we have failed to educate for uncertainty (17).

Philosophers and poets, judges, and scientists have all given testimony. Judges who have to make difficult decisions say it well. Learned Hand wanted Oliver Cromwell's statement, "Consider ye, in the bowels of Christ, ye may be mistaken" engraved over every courthouse, every church, and every crossroads in the nation (18). Justice Holmes wrote "Every year, if not every day, we have to wager our salvation upon some prophecy based upon imperfect knowledge" (19). David Bazelon has described the difficulty, even anguish, of decision concerning guilt of an alleged transgressor if he is retarded or disturbed and poor in the bargain (20).

Jacob Bronowski, philosopher-mathematician, has reinterpreted Heisenberg's "Principle of Uncertainty" as a "Principle of Tolerance." He writes, "All information is imperfect. We have to treat it with humility (21)." He writes of Gauss: "...When an observer looks at a star, ... he takes several readings, and he hopes, naturally, that the best estimate of the star's position is the average - the center of the scatter....He devised the Gaussian curve...And from this came a far-reaching idea: the scatter marks an area of uncertainty. We are not sure that the true position (of the star) is the center. All we can say is that it lies in the area of uncertainty." I thank William Glazier, one of Bronowski's former colleagues at the Salk Institute for calling this essay to my attention. How limited to have thought of the Gaussian curve as a tool for calculating means and standard deviations! I had succumbed to what John Peters called "The Tyranny of Numbers." (Some of you may have known Dr. Peters as senior author of the bible of yesteryears, Quantitative Clinical Chemistry. Others may have known him also as a fighter against other tyrannies, those of Franco's Spain during the 1930's, and the "Tyranny of Labels" with which he was plagued all the way to the Supreme Court of the United States. The case was thrown out, but to Dr. Peter's disgust, on a technicality (22).)

Over the century after Gauss, Heisenberg, arguing about subatomic particles developed the "Principle of Uncertainty." Bronowski writes: "We know that we cannot ask the world to be exact... Yet the Principle of Uncertainty is a bad name. In science or outside it, we are not uncertain; our knowledge is merely confined within a certain tolerance. We should call it the Principle of Tolerance....Science has...understood that the exchange of information between man and nature, and man and man, can only take place with a certain tolerance...."

He ends the chapter thus: "Science is a very human form of knowledge....Every judgment in science stands on the edge of error, and is personal.... We have to cure ourselves of the itch for absolute knowledge and power. We have to close the distance between the push button order and the human act. We have to touch people."

Since dealing with people requires a greater tolerance for uncertainty, comfort with the search for, or only with, certainty, leads clinicians into teaching which is necessary but inadequate to the greater purposes of medicine: the help of people whose complaints, regardless of their nature, bring them to the doctor.

I hope my friends in neonatology will forgive me the choice of examples. It is good that neonatologists can discuss a prematurely born infant with respiratory insufficiency in terms of currently accepted information about intrauterine diagnosis, appropriateness of weight for gestational age, lung maturation, respiratory and circulatory physiology, blood gases, blood $\mathrm{Ph}$, and the results of other modern monitors as a guide to therapy. There exist, however, large gray areas about outcome. Discussion with the parents concerning future development of a specific baby is difficult because of uncertainty. The attending neonatologist usually leaves this to the house officer and the house officer has to fall back on statistical predictions which are changing and based on multifactorial data inherently difficult to evaluate. How does it help a mother and father if one says that the chances for neurologic deficit are 3 or 8 in 10, when one can't say into which category their infant falls nor predict the nature of the deficit? What is "the truth" one tells when one doesn't know the truth to tell? The doctor may know little of the mother-infant bonding, the family interactions, and social conditions which will affect the infant's future development. Isn't it demanded by science that one recognize the limits of our information? Shouldn't we try to learn more about environmental circumstances that will affect development after discharge from the nursery? Isn't it better that one try to allay anxiety by offering to the parents continuing help in ambulatory services to the extent that increasing knowledge is available if or when the problems arise? The majority of rotating students, however, emulating rotating house officers who emulate the majority of full time attendings with primary devotion to other worthwhile pursuits prefer to be on the inpatient service. Here one can walk off the ward emotionally satisfied by the advanced technologic measures used in diagnosis and therapy, even when the evaluation is of necessity incomplete. How many attending neonatologists or fellows are willing, as part of their new subspeciaity, to give continuing care to high risk infants after discharge from the nursery, to wrestle with the ambiguities of "soft signs" of neurologic damage which may disappear with maturation, the learning disabilities which are not recognized until school age, the behavior problems, which may represent minimal brain damage or impoverished contact with the mother immediately after birth, the anger of the distraught parent of a child with severe cerebral palsy, frustrated by the limits of our therapy, by her poverty, and by the bureaucratic delays of our institutions of health, education, and welfare?

Will the new subspecialty board in neonatology question candidates in depth about how they try to help the grieving parents of infants who have died or who have multiple congenital malformations? "Pastoral counseling" is not a pejorative term; ministering to the sick is not an accident of semantics. Schulz, indulging in the hyperbole of the Peanuts cartoon, has Peppermint Pattie say, "You've never understood, Marcie, when a person complains, he doesn't want a solution, he wants sympathy." Of course, the patient should have both. This is what Bronson Crothers meant when he said that the prime purpose of the physician was to allay anxiety and that the diagnosis and cure of disease was a fine, but only one, method.

Counseling parents with such problems requires an excellence in understanding and sensitivity which are not easily taught or measured, a tolerance for uncertainty which constitutes a particular kind of elitism. How can we ask parents to cope with uncertainty when we ourselves avoid it? Those who equate elitism exclusively with specialism, clinical, or laboratory science are unintentionally arrogant, for they constrict the definition to pursuit of their own tastes, worthwhile though these may be. I 
believe this tolerance for uncertainty can and must be taught at the same time that one quests for certainty. Scientific accuracy-an understanding of Gauss and Heisenberg and Bronowski-demands that we do so, by indicating to students and house officers the limitations of our data, the uncertainty on which we base our answers to the questions we urge them to ask. A certainty more apparent than real is a potentially dangerous inaccuracy.

\section{THE SALARIED SYSTEM FOR TEACHERS OF CLINICAL MEDICINE}

I turn now to the second part of my concern: an occupational hazard posed to teachers of clinical medicine by the so-called full time system. I say "so-called full time." Valid intellectual responsibilities to extramural funding agencies, and hypertrophy and hyperplasia of committees resulting from the size of our medical centers and the growth of "participatory democracy" have made many senior full time teachers visitng professors in their own departments, even when they are not out of town. This is hardly a good model for younger faculty and students.

The song is old. Sir William Osler, whose presidential address before this society in 1892 concerned itself with the growth of specialism, wrote a controversial letter to President Remsen of Hopkins in 1911 from his Oxford abode. He expressed concern that a salaried system for teachers of clinical medicine that did not permit them a few private patients would direct them toward a research course and away from teaching. He wrote: "Let me thank you, first, for Mr. Flexner's report. As an Angel of Bethesda, he has done much good in troubling our fish pond, as well as the general pool. The Report as a whole shows the advantage of approaching a problem with an unbiased mind, but there are many mistakes from which a man who knows the profession from the outside only, could not possibly escape." The concept of a system of completely salaried clinical teachers at Hopkins had been the subject of earlier discussion by Mall, Howell, and Welch who, incidentally, had been urged by his friend, Jacobi, to visit German university clinics (23). From remarks made in Florence Sabin's biography of Mall, I hazard a guess that perhaps Osler was firing a dart at his former preclinical colleagues as well as at Flexner, particularly at Mall, who had urged full time for clinical teachers soon after he went to Hopkins from the University of Chicago in 1893 (24). Osler was also concerned that salaried teachers would lose touch with private practitioners and the community.

Having enjoyed a salaried career throughout my professional life, and with a deep, deep appreciation of the benefits that salaried laboratory and clinical scientists have brought, bring, and need to continue to bring to care of patients by their research and teaching, I find myself impressed with Dr. Osler's foresight, but for a slightly different reason, perhaps implicit in his letter.

Many completely salaried clinical teachers have been cut off from direct involvement with their patients' personal and family problems, even though more reasonable therapy and therefore better compliance require such involvement. It is easy to understand what happens: a clinician whose salary comes partly or wholly from research funds will, of course, pursue his research. The enjoyment of quenching one's intellectual curiosity is reinforced by a prudent concern for one's own family needs. The academic clinician will do this rather than attempt, by direct involvement, to learn more about ambiguous facets of care that are less under his control. His curiosity about people, rather than about disease, organs, or orifices and, therefore, his skills as a teacher of comprehensive medicine will atrophy, or worse yet, fail to develop. This he can prevent by having some patients for whom he is responsible in a continuing, and not just consultative, way. If he is able, despite current economic developments in this country, too, to choose not to see private patients, then he should turn, on a continuing basis, to the outpatient department, either the general or specialty clinics or both. Here, he will find it necessary to breach the defensive shield of medical students, house officers, and clinical fellows who are quite prepared to keep him in the corridor, away from the patient or parent; he must not walk away salving his conscience with the rubric "Responsibility Teaches."

The dilemma of the salaried clinical teacher exists because the system was established to limit his interests to those of the university, "teaching and thinking." But what to do about patient care, which was and is no part of the responsibility of nonclinical teachers, such as those at the Hopkins who urged the salaried system for clinicians too?

Shopenhauer described the porcupine's dilemma (25). If porcupines come too close, they prick each other. If they keep their distance, they become cold. My concern is for the clinical teacher who has been away from direct involvement with patients so long he doesn't even recognize that he appears cold to students. He may be teaching what he knows very well, and this is worthy of emulation; but he doesn't serve as a model for doctors who should at least attempt to meet the felt needs of their patients.

To give such care seems a matter of justice; it is what we want for ourselves and our families. This simply stated standard is frequently not met, for example, in the use of excessive diagnostic examinations or in failure to share decision making with patients and their families. The fact that our arrogance is unintentional makes it no more acceptable. Sophisticated patients rightfully object, and they are increasing in numbers among all social classes partly as a result of mass media, and partly as a result of the civil rights movement. Patient advocate offices and consumer advisory boards challenge our authoritarian ways; answering their questions will surely improve the care of patients and our teaching skills just as do attempts to answer the challenging questions of our students.

Furthermore, we would do well to request more teaching by well trained private practitioners who have not permitted the inefficiency, size, or lucrativeness of their practices to distort their professional and personal lives. The ability to use a "disciplined intuition" (26) in making quickly what are essentially statistical decisions with incomplete data is a skill to be acquired with experience, both in the well trained private practitioner's office and in the properly manned and supervised general outpatient department. The directly sensed gratitude of parents, more available in the outpatient department because more parents are there, represents a fee-for-service for clinical teachers not subject to income tax, hospital, or university overhead.

In summary, for the benefit of our students, we must first develop a tolerance for uncertainty while we encourage the quest for certainty. Secondly, we must address ourselves to the occupational hazards of the full time salaried system by encouraging clinical teachers to become directly involved with patients on a continuing basis. Thirdly, we must make more room on our faculties for private practitioners.

The answer to T. S. Eliot's question:

Where is the wisdom we have lost in knowledge?

Where is the knowledge we have lost in information?

will be derived from development of comfort with the color gray, and demonstration, especially by senior teachers, that there is an excellence, as challenging as any, in dealing with people and their ambiguities.

If you agree with what I have said don't hesitate to fight for this point of view, within your own department, with members of other departments, particularly if you are in an institution which would benefit from "tilting." If you disagree, do not brush my remarks aside. Examine them carefully-hopefully they will produce tension. A respected lecturer once said that if he didn't have a sense of tension in dealing with complex issues, he worried that he was missing something.

McDermott has recently written that one requirement of a satisfactory system of general medical care is "an appropriate science-based Samaritanism" (27). I would modify this to say that helping people is the primary purpose of medicine, and that clinical 
and laboratory science, modern technology, improved systems of delivery, allied health professions, are all its handmaidens.

I conclude with excerpts from two letters. One was received from Dr. Park in June 1969, a month before he died at age 92, and while I was still in the dean's office:

But my idea for you was as an investigator of disease as you began, an artist rather than the curator of a museum, even a great one. However, the mother of T. S. Eliot wrote a letter to Bertrand Russell expressing doubts, fears and misgivings that her son was headed for poetry. The best life is when one can do most for others and when life is over, what does some tiny progress in knowledge in some tiny area amount to? Perhaps only the assurance to oneself in having been a faithful soldier to the end...

With all good wishes and regrets that our ships no longer are in the same harbor,

Ned Park (s)

Second, from Dr. Powers who first turned me toward academia and, as the "companion of my silence" is still my major role model, an excerpt from a letter to his staff at the dedication of a study-conference room:

Gratitude: E. A. Robinson says of it-

Two kinds of gratitude, the sudden kind

We feel for what we take, the large kind

We feel for what we give.

So in the end, the example of Powers and Park, Park and Powers gives an answer to the dilemmas I have discussed- "the rest is commentary."

\section{REFERENCES AND NOTES}

1.a. Marine, D., and Kimball, O. P.: Prevention of simple goiter in man. Arch. Int. Med., 25: 661, 1920.

b. Marine, D., and Baumann, E. J.: Duration of life after suprarenalectomy in cats and attempts to prolong it by injections of solutions containing sodium salts, glucose, and glycerol. Amer. J. Physiol., 81: 86, (1927).

c. Marine, D.: Presentation of Kober Medal (by R. H. Follis, Jr). Trans. Ass. Amer. Phys., 78: 51 (1960).

2.a. Powers, G. F.: Comparison and interpretation on a caloric basis of the milk mixtures used in infant feeding. Amer. J. Dis. Child., 30:453 (1925).

b. Powers, G. F.: Remarks to undergraduate students of clinical medicine. Yale J. Biol. Med., 22: 109 (1949).

c. Powers, G. F.: John Howland Award Address: The retarded child and his family as a challenge to pediatric practice, research and education (Introduction by D. C. Darrow). Pediatrics, 12:217 (1953).

d. Powers, G. F.-In Memoriam (by H. H. Gordon). Yale J. Biol. Med., 42: 39 (1969).

3.a. Schloss, O. M.: A case of allergy to common foods. Amer. J. Dis. Child., 3: 361 (1912).

b. Schloss, O. M., and Stetson, R.: The occurrence of acidosis with severe diarrhea. Am. J. Dis. Child., 13: 218 (1917).

c. Schloss, O. M.: Intestinal intoxication in infants; the importance of impaired renal function. Amer. J. Dis. Child., 15: 165 (1918).

d. Schloss, O. M.: Profile (by H. H. Gordon) In B. Veeder: Pediatric Profiles (C. V. Mosby Co., St. Louis, 1957).

4.a. Levine, S. Z., Wilson, J. R., and Kelly, M. D.: The insensible perspiration in infancy and in childhood. I. Its constancy in infants under standard conditions and the effect of various physiologic factors. Amer. J. Dis. Child., 37: 791 (1929).

b. Levine, S. Z., Wheatley, M. A., McEachern, T. H., Gordon, H. H., and Marples, E.: Respiratory metabolism in infancy and in childhood. XXI. Daily water exchange of normal infants. Amer. J. Dis. Child., 56: 83 (1938).

c. Levine, S. Z.: Child health abroad-Some personal observations-John Howland Award Address (Introduction by H. L. Barnett). J. Pediat. 65: 992 (1964).

5.a. Dunham, E. C.: Septicemia in the newborn. Amer. J. Dis. Child., 45: 229 (1933).

b. Dunham, E. C., and McAlenney, P. F., Jr.: A study of 244 prematurely born infants. J. Pediat., 9: 717 (1936).

c. Dunham, E. C.: Premature Infants, a Manual for Physicians (Publication no. 325, United States Government Printing Office, Washington, D.C., 1948).

d. Dunham, E. C.: John Howland Award Address (Introduction by H. H. Gordon). Amer. J. Dis. Child., 94: 367 (1957).

6.a. Washburn, A. H.: Blood cells in healthy young infants. I. The leukocyte picture during the first three months with special reference to hourly and daily variations. Amer. J. Dis. Child., 47: 993 (1934). b. Washburn, A. H.: Growth, its significance in medicine viewed as human biology. Pediatrics, 5: 765 (1950).

c. Washburn, A. H.: Pediatric potpourri. Pediatrics, 8: 299 (1951).

d. Dr. and Mrs. Alfred H. Washburn: Letter to the Editor (by H. H. Gordon with editor's note by C. A. Smith). Pediatrics, 50:822 (1972).

7.a. Ruegamer, W. R., Bernstein, L., and Benjamin, J. D.: Growth, food utilization and thyroid activity in the albino rat as a function of extra handling. Science, 120: 184 (1954).

b. Benjamin, J. D.: Knowledge, conviction and ignorance. J. Med. Ed., 36: 117 (1961)

c. Benjamin, J. D.: The innate and the experiential in development. In H. W. Brosin: Lectures on Experimental Psychiatry, pp. 19-42 (University of Pittsburgh Press, Pittsburgh, Pa., 1961).

d. Benjamin, J. D.: 1901-1965, Obituary (by H. S. Gaskill). J. Nerv. Ment. Dis., 142: 1 (1966).

e. Metcalf, D. R.: The effect of extrauterine experience on the ontogenesis of EEG sleep spindles. Psychosomat. Med., 31: 393 (1969)

8. Escalona, S.: The present state of knowledge and available techniques in the area of cognition. In D. P. Purpura and G. P. Reaser: Methodological Approaches to the Study of Brain Maturation and its Abnormalities, National Institute of Child Health and Human Development-Mental Retardation Research Centers Series, pp. 135-140 (University Park Press, Baltimore, 1974).

9.a. Sabin, F. R.: Model of the medulla, pons and midbrain of a newborn babe Johns Hopkins Hosp. Rep., 9: 925 (1900).

b. Sabin, F. R.: Studies of living human blood cells. Johns Hopkins Hosp. Bull., 34: 277 (1923).

c. Bluemel, E.: Florence Sabin, Colorado Woman of the Century. (University of Colorado Press, Boulder, Colo., 1959).

d. Harvey, A. M.: A new school of anatomy: The story of Franklin P. Mall, Florence R. Sabin and John B. MacCallum. The Johns Hopkins Med. J., 136: 83 (1975)

10.a. Park, E. A.: A case of hypersensitiveness to cows' milk. Amer. J. Dis. Child., 19: $46(1920)$

b. Park, E. A.: Observations on the pathology of rickets with particular reference to the changes at the cartilage-shaft junctions of the growing bones. Harvey Lect. Ser., 34: 157 (1938 1939).

c. Park, E. A.: Acceptance of the Kober Medal Award-Presentation by James L. Gamble, Sr., Trans. Ass. Amer. Phys., 63: 21 (1950)

d. Park, E. A.: John Howland Award Address (Introduction by G. F. Powers). Pediatrics, 10: 82 (1952).

e. Park, E. A.: Foreword to McCollum, E. V., From Kansas Farm Boy to Scientist (University Press of Kansas, Lawrence, Kansas, 1964).

f. Taussig, H. B.: John Howland Award Address. Pediat. Res., 5: 569 (1971).

11. Eddington, C. H.: The Ethical Animal (George Allen and Unwin, Ltd., London, 1960).

12. McDermott, W.: Modern medicine and the demographic-disease pattern of overly traditional societies: A technologic misfit. J. Med. Ed. 41: 137 (1966)

13. Korsch, B. M., Gozzi, E. K., and Francis, V.: Gaps in doctor-patient communications. Pediatrics, 42: 855 (1968)

14. Helfer, R. E., and Ealy, K. F.: Observations of pediatric interviewing skills-a longitudinal and cross-sectional study. Amer. J. Dis. Child, 123: 556 (1972).

15. Duff, R. S., and Hollingshead, A. B.: Sickness and Society (Harper and Row, New York, 1968).

16. Richmond, J.: Currents in American Medicine: A Developmental View of Medical Care and Education (Harvard University Press, Cambridge, Mass., 1969).

17. Whitehorn, J. C.: Education for uncertainty. Perspect. Biol. Med., 7: 118 (1963)

18. Hand, L.: Spirit of Liberty (papers and addresses edited by Irving Dilliard). (A. A. Knopf, New York, 1952).

19. Holmes, O. W. Dissenting in Abrams vs. U.S., 250 US616 (quoted by Barth, A. A.). Prophets with Honor-Great Dissents and Great Dissenters in the Supreme Court, pp. 248 (A. A. Knopf, New York, 1974).

20. Bazelon, D.: Dissenting opinion in U.S.A. vs. Murdock, U.S. Court of Appeals for the District of Columbia Circuit no. 23783, pp. 79-85, decided April 21, 1972

21. Bronowski, J.: Knowledge or certainty, Chapt. 11. The Ascent of Man, p. 353, (Little, Brown \& Co., Boston/Toronto, 1973).

22. Personal letter dated May 24, 1974 from Dr. Richard Peters, Professor of Surgery and Bioengineering, University of California, San Diego.

23. Chesney, A. M.: The Johns Hopkins Hospital and the Johns Hopkins University School of Medicine, Vol. III, p. 128, pp. 176-183, 1905-1914 (The Johns Hopkins Press, Baltimore, 1963)

24. Sabin, F. R.: Franklin Paine Mall: The Story of a Mind (The Johns Hopkins Press, Baltimore, 1970).

25. Bellak, L.: The Porcupine Dilemma: Reflections on the Human Condition (Citadel Press, New York, 1970).

26. Bruner, J.: Toward a disciplined intuition, Chapt. 5. In: The Relevance of Education, p. 82 (W. W. Norton \& Co., New York, 1971).

27. McDermott, W.: General medical care-Identification and analysis of alternative approaches. The Johns Hopkins Med. J., 135: 292 (1974).

28. This address was presented at the Annual Meeting of the American Pediatric Society, Denver, Colorado, April 17, 1975.

29. Appreciation is expressed to Mr. William Glazier of the Department of Community Health, Ms. Patricia Rainford, Patient Advocate, and Drs. Bertrand Bell and Milford Fulop of the Department of Medicine of Albert Einstein 
College of Medicine for illuminating discussions during preparation of this address. They bear no responsibility for the opinions expressed.

30. Dr. Harry H. Gordon is NARC-Grover F. Powers Professor of Pediatrics, and Director Emeritus, Rose F. Kennedy Center for Research in Mental Retardation and Human Development, Albert Einctein College of MedicineYeshiva University.
31. Preparation of this paper was helped by Grants nos. HD 01799 and SRS 59-9. 10277 from the National Institutes of Health.

32. Requests for reprints should be addressed to: the author, 1300 Morris Park Avenue, Bronx, New York, 10461.

33. Accepted for publication December 8, 1975.

Copyright (C) 1976 International Pediatric Research Foundation, Inc. 